\title{
Suitability of Prunus Selections as Hosts for the Ring Nematode (Criconemella xenoplax)
}

\author{
S.W. Westcott, III ${ }^{1}$, E.I. Zehr ${ }^{1}$, W.C. Newall, Jr. ${ }^{2}$, and D.W. Cain ${ }^{3}$ \\ Clemson University, Clemson, SC 29634 \\ Additional index words. cherry, peach, peach tree short life, plant-parasitic nematode, plum, resistance
}

\begin{abstract}
Prunus accessions were screened in a greenhouse for suitability as hosts for Criconemella xenoplax (Raski) Luc and Raski. All 410 accessions examined were suitable hosts for the nematode. Included in this study were 266 Prunus persica L. Batsch cultivars and cultivars representing 25 other Prunus species: P. americana Marsh., P. andersonii A. Gray, $P$. angustifolia Marsh., $P$. argentea (Lam.) Rehd., $P$. armeniaca L., $P$. besseyi L. H. Bailey, $P$. cerasifera Ehrh., $P$. cistena N.E. Hansen, P. davidiana (Carriere) Franch., P. domestica L., P. dulcis (Mill.) D. Webb, P. emarginata (Dougl. ex Hook.) Walp., P. hortulana L. H. Bailey, P. insititia L., P. kansuensis Rehd., P. maritima Marsh., P. munsoniana W. Wright \& Hedr., P. pumila L., P. salicina Lindl., P. simonii Carriere, P. spinosa L., P. tenella Batsch, P. texana D. Dietr., P. tomentosa Thunb., and $P$. webbii (Spach) Vierh. Also, another 66 interspecific hybrids were tested. Although a few accessions seemed to exhibit an unstable form of resistance, it seems unlikely that Prunus selections that exhibit useful resistance to population increase by $C$. xenoplax will be found.
\end{abstract}

Peach trees often die prematurely when grown in sandy soils in the southeastern United States (Dozier et al., 1984). The ring nematode, Criconemella xenoplax [Mesocriconema xenoplax (Raski) Loof and DeGrisse], seems to be a major contributor to this problem (Nyczepir et al., 1983), and controlling nematodes improves tree survival (Chandler, 1969; Ritchie, 1984; Zehr and Golden, 1986;Zehretal., 1976, 1982). Therefore, selecting rootstocks that are unsuitable hosts for the ring nematode was proposed as a way to increase longevity of peach trees on infested sites.

Criconemella xenoplax reproduces on many Prunus spp. besides $P$. persica, including P. dulcis (Seshadri, 1964), P. armeniaca (Lownsbery, 1964), P. avium (L.) L. (Lownsbery, 1964), $P$. cerasifera (Mojtahedi and Lownsbery, 1975), P. domestica (Goodey and Franklin, 1956), P. mahaleb L. (Lownsbery, 1964), and $P$. moseri ( $P$. cerasifera var. atropurpurea) (Mojtahedi and Lownsbery, 1975). Six interspecific hybrids from various Prunus spp. have supported ring nematode reproduction (Mojtahedi and Lownsbery, 1975). To our knowledge, few Prunus selections have been examined for host suitability to C. xenoplax.

Our objective was to discover Prunus selections that supported little or no population increase by $C$. xenoplax in greenhouse trials. Methods have been developed to identify individual Prunus seedlings that inhibit nematode reproduction, and a wide variety of accessions has been examined. Part of this study has been summarized (Cain et al., 1988; Westcott and Zehr, 1991).

\section{Materials and Methods}

Seeds and cuttings were collected from accessions grown in a Prunus germplasm collection at Clemson Univ., S.C., and from the Sandhills Research and Education Center, Elgin, S.C. Seeds were stratified for 12 to 15 weeks and planted after the radicle emerged.

Received for publication 18 Oct. 1993. Accepted for publication 22 Dec. 1993. Technical contribution no. 3493 of the South Carolina Agricultural Experiment Station, Clemson Univ., supported by state funds and by U.S. Dept. of AgricultureAgricultural Research Service special grants 85-CRSR-2-2573 and 87-CRSR-22999. We thank Judith White and Lynn Luszcz for technical assistance and P.M. Burrows for advice. The cost of publishing this paper was defrayed in part by the payment of page charges. Under postal regulations, this paper therefore must be hereby marked advertisement solely to indicate this fact.

${ }^{1}$ Dept. of Plant Pathology and Physiology.

${ }^{2}$ Dept. of Horticulture.

${ }^{3}$ Sun World, 16350 Driver Rd., Bakersfield, CA 93311.
Cuttings from field-grown trees were treated with indole-3-butyric acid $\left(2 \mathrm{mg} \cdot \mathrm{g}^{-1}\right)$ and rooted under mist in a peat-lite mixture containing $0.42 \mathrm{~g} \cdot \mathrm{liter}^{-1}$ each of $\mathrm{N}, \mathrm{P}$, and $\mathrm{K}$ as mixed salts from a commercial slow-release fertilizer. Cuttings from seedlings grown in the greenhouse were rooted in a similar manner but without auxin. All soil used in greenhouse tests was steamed at 60 to $70 \mathrm{C}$ for $30 \mathrm{~min}$.

Tests in 1985-86. Six 2-week-old seedlings from each accession were transplanted to plastic pots containing 2.5 liters of Lakeland sand ( $89 \%$ sand, $6 \%$ silt, $5 \%$ clay). Soil containing $\approx 500$ adults and juveniles of $C$. xenoplax was added to each pot 7 weeks after transplanting. Plants were fertilized at 2-week intervals (Eayre et al., 1987). After an additional 10, 14, and 24 weeks for three experiments, respectively, nematodes were extracted from $20 \%$ of a $500-\mathrm{cm}^{3}$ sample of soil from each pot by elutriation for $4.25 \mathrm{~min}$ at a flow rate of $\approx 60 \mathrm{ml} \cdot \mathrm{s}^{-1}$ (Byrd et al., 1976) followed by centrifugal flotation (Jenkins, 1964). Seven accessions were common to all three experiments.

Values for final population density of nematodes per plant without correcting for extraction efficiency $\left(\mathrm{C}_{\mathrm{f}}\right)$ were transformed by computing the natural logarithm of $\mathrm{C}_{\mathrm{f}}+1$. The portion of total variance attributable to differences among accessions was determined by estimating the variance component associated with accessions. Results for each experiment were evaluated by normal order statistics to detect those accessions of interest for further study. the observed SD $\left(\mathrm{O}_{\mathrm{x}}\right)$ from the population mean was estimated as

$$
\mathrm{O}_{\mathrm{x}}=\left(\mathrm{L}_{\mathrm{x}}-\mathrm{M}\right) / \mathrm{E}
$$

where $L_{x}$ is the average for each accession of the transformed values, $M$ is the average value within each experiment, and $E$ is the SE attached to $L_{x}$.

After ordering from smallest to largest, these sDs were compared with their expected values, $\xi\left(\mathrm{X}_{\mathrm{i} \mid \mathrm{n}}\right)$ estimated according to Harter (1961):

$$
\xi\left(\mathrm{X}_{\mathrm{i} \mid \mathrm{n}}\right)-\Phi^{-1}[(\mathrm{i}-\alpha) /(\mathrm{n}-2 \alpha+1)]
$$

where $\Phi^{-1}$ is the Probit transformation and $\mathrm{X}_{\mathrm{i} \mid \mathrm{n}}$ is the $\mathrm{i}^{\text {th }}$ largest after ordering a sample size of $n ; \alpha$ was taken to be 0.4 for sample sizes included in this study.

Tests in 1987-90. Seedlings and cuttings were screened for host 
suitability according to the methods of Westcott and Zehr (1991). Results from these greenhouse tests are reported in terms of $\beta$, an estimate of degree-days required for the nematode population to double. Under the average conditions in our experiments, the estimated $\beta$ for a suitable host is 139 degree-days (Westcott and Burrows, 1991). An increase in $\beta$ indicates a decrease in the suitability of a given host. Under this evaluation system, plants that initially seem to inhibit nematode population increase are tested additional times, and rooted cuttings from the plant may be tested to support or refute the presumed resistance to the nematode. Data were not transformed before analysis. Results for all experiments were compiled, and the variance component associated with accessions was determined. The results were evaluated by normal-order statistics as described above, except that accessions were ordered from largest to smallest to maintain the same functional order relative to host suitability.

A score was determined for each accession to reflect its relative host suitability based on all observations available. To combine information from all experimental systems, a percentile ranking for each accession in each experiment conducted in 1985-86 and in the combined results of all experiments conducted in 1987-90 was calculated. This resulted in four groups of ranked accessions. Where an accession was included in more than one group, a weighted average of the percentile ranking was determined. The number of observations was used as the weighting factor. This provided a single score of relative host suitability for each accession. Three selection levels were established. Those of most interest had a score $\leq 11 \%$ with 10 or more observations. Selections of possible interest were those with low scores $(\leq 15 \%)$, but very few observations $(\leq 10)$. All other selections were considered to be highly suitable hosts for the nematode.

\section{Results}

More than 4270 seedlings representing 410 accessions were screened. Most were highly suitable hosts for C. xenoplax, but a few that seemed to be relatively poor hosts may be of further interest. Some of these poor hosts were identified by few observations and must be evaluated more extensively to be confident of their placement.

Tests in 1985-86. The average nematode population densities

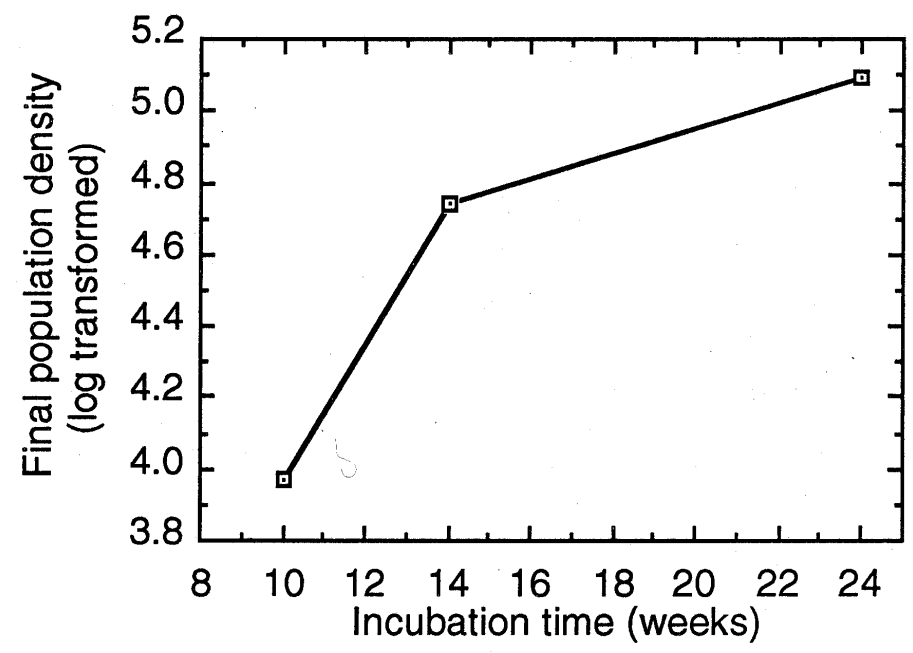

Fig. 1. Final nematode population density (log transformed) of Criconemella xenoplax on a variety of Prunus accessions for experiments incubated for 10, 14, and 24 weeks. per $100 \mathrm{~cm}^{3}$ soil for the three experiments were 52 after 10 weeks, 114 after 14 weeks, and 161 after 24 weeks. The relationship between logarithm-transformed averages and incubation periods indicates that nematode population increase slowed between 14 and 24 weeks of incubation (Fig. 1). The percentage variance component associated with differences among accessions was $11 \%$ after 10 weeks, $19 \%$ after 14 weeks, and $15 \%$ after 24 weeks. In all three experiments there seemed to be a strong effect associated with differences among accessions (Fig. 2).

In the experiment incubated for 10 weeks, 15 accessions seemed able to inhibit nematode population increase (Fig. 2A). Twelve
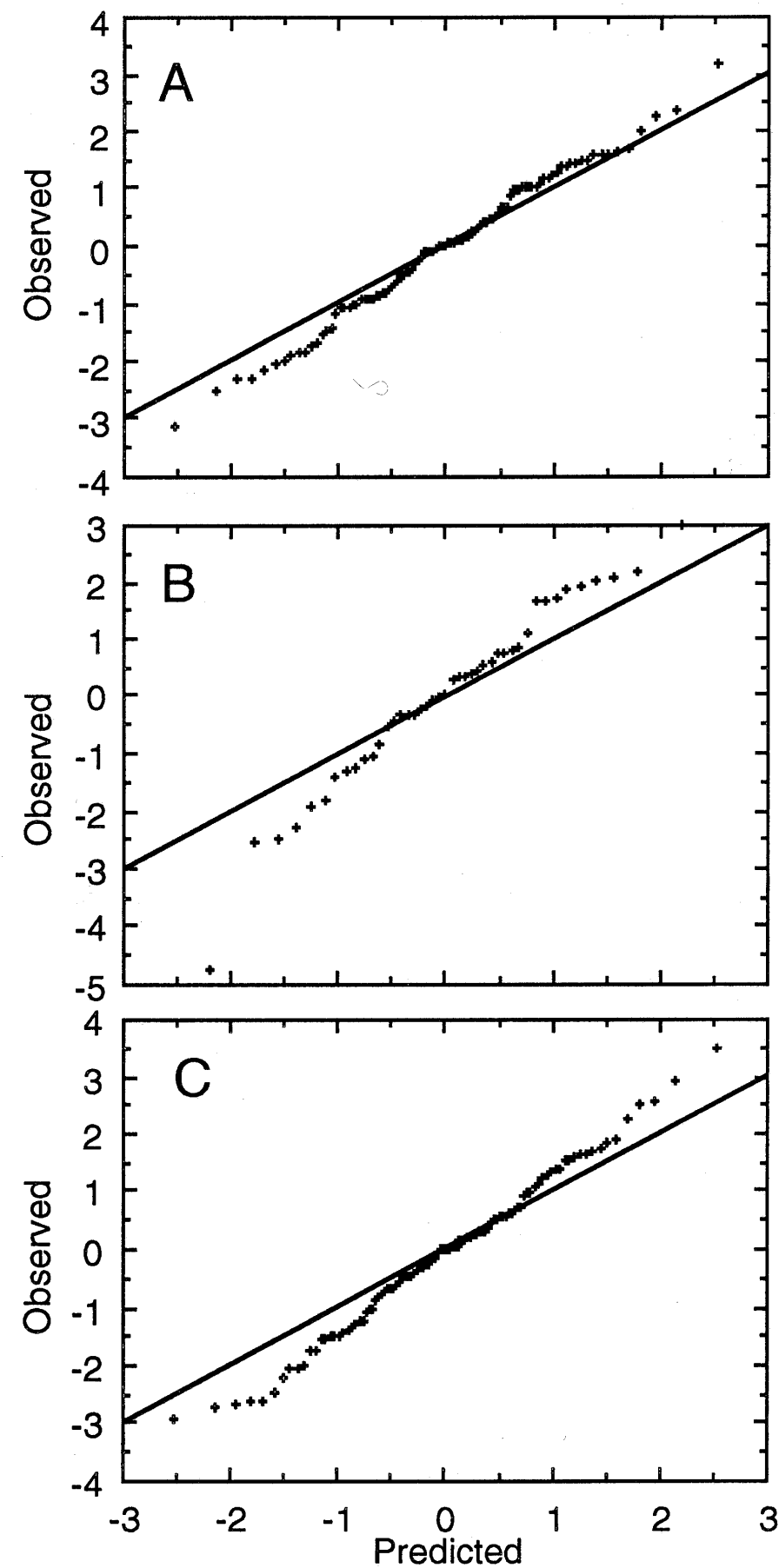

Fig. 2. For final population density measurements, the observed compared to the expected SD from the nematode population mean ( $\log$ transformed) determined by normal-order statistics for peach seedlings under conditions described for experiments conducted in 1985-86 for (A) 10, (B) 14, and (C) 24 weeks. 
were selected from the experiment incubated for 14 weeks (Fig. 2B) and 26 were selected from the experiment incubated for 24 weeks (Fig. 2C). Of these accessions, Montclar and Siberian C were included in all three experiments but were not among those with a low nematode population density in any experiment. Selection of some accessions was based on only one or two observations. Since many of these were examined further in subsequent tests, final ranking was determined after including all subsequent observations.

Tests in 1987-90. The least squares mean for rating nematode host suitability (Westcott and Zehr, 1991) was 199 degree-days for doubling an increment of the nematode population. The reaction of accessions based on $\beta$ did not seem to be normally distributed (Fig. $3)$. Forty-two accessions seemed to inhibit nematode population increase (Fig. 3), but some of these had been examined in previous experiments and were highly suitable hosts. Conversely, many identified as potentially unsuitable hosts in the previous experiments were highly suitable nematode hosts.

Based on a relative host suitability score, 23 accessions seemed to support slower nematode population increase than other accessions tested (Table 1). Although these are scored as the least suitable hosts, they can support substantial nematode populations. No accessions were highly resistant as hosts. Another 22 accessions were scored as poor hosts after limited testing (Table 2), but these require more extensive testing to fully characterize their suitability as hosts. All others tested were considered highly suitable hosts for $C$. xenoplax.

Of those considered highly suitable, 192 accessions have been examined fewer than 10 times. This list includes members of 15 species and various interspecific hybrids. These are separated from other highly suitable hosts that were more thoroughly tested because of the tentative nature of their classification with the highly suitable hosts. Included in this group were Hangchow; $P$. angustifolia; $P$. angustifolia hybrid 'Blue Goose'; P. emarginata; P. maritima IR 427-2-3; P. pumila IR 333-2; P. tenella; $P$. armeniaca HW 408; P. besseyi $2-1$; six accessions of $P$. cerasiferMyrobalan B IR 871-2, Ohio 2 IR 421-3, Wa 106 IR 769-2, Wa 1210 IR 373-1, and Wa 734 IR 369-1 — and one unnamed accession; five accessions of $P$. dulcis -Amara, F1(R.486x dehiscens)2, Mission, Ruby, and Titan IR 934-1; three accessions of $P$.

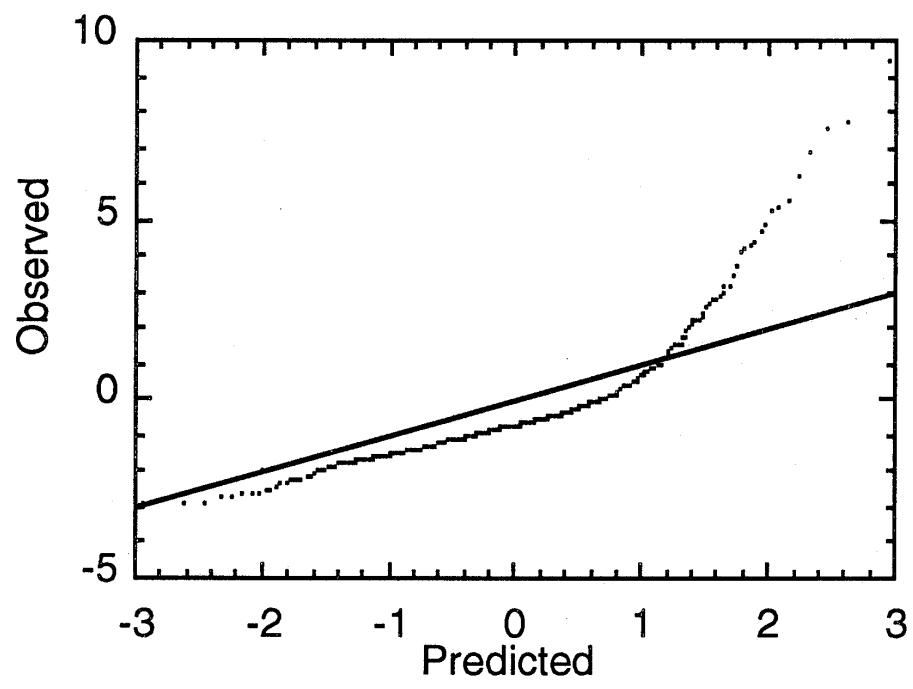

Fig. 3. For doubling constant $(\beta)$ measurements, the observed compared to the expected SD from the population mean determined by normal-order statistics for peach seedlings incubated with nematodes under conditions described for experiments conducted in 1986-90.
Table 1. Prunus accessions scored as most limiting of Criconemella xenoplax population increase. The number of observations $(\mathrm{N})$, host suitability score, doubling constant (b), and its SE are shown.

\begin{tabular}{lccrrr}
\hline \hline Accession $^{z}$ & Type $^{\mathrm{y}}$ & $\mathrm{N}$ & Score & \multicolumn{1}{c}{ b } & SE \\
\hline Bounty (Assiniboine op) & $\mathrm{P}$ & 18 & 5 & 272 & 25 \\
Chui Lum Tso & $\mathrm{P}$ & 27 & 6 & 339 & 22 \\
Damas GF 1869 [M x O] & $\mathrm{I}$ & 14 & 4 & 364 & 35 \\
Freestone Goose & $\mathrm{U}$ & 69 & 9 & 224 & 13 \\
Giallo Di Padova PI 65977 & $\mathrm{P}$ & 11 & 11 & 245 & 32 \\
Hann & $\mathrm{D}$ & 19 & 8 & 249 & 24 \\
Hui Hun Tao & $\mathrm{P}$ & 33 & 9 & 231 & 18 \\
J.L. Budd & $\mathrm{A}$ & 44 & 2 & 282 & 16 \\
Kahinta IR 552-2 [probably S x E] & $\mathrm{I}$ & 41 & 3 & 292 & 17 \\
Manor IR 929-1 (Sapa op) & $\mathrm{I}$ & 41 & 7 & 237 & 16 \\
P. argentea & & 12 & 11 & 243 & 30 \\
$P$. besseyi & & 98 & 1 & 281 & 11 \\
P. davidiana X almond F5 22-11 & $\mathrm{I}$ & 11 & 11 & 243 & 32 \\
$P$. kansuensis (Ark) & & 86 & 2 & 254 & 11 \\
P. pumila 'Mando' & & 53 & 1 & 301 & 15 \\
Redcoat [S 'Burbank' x E 'Wolf'] & $\mathrm{I}$ & 83 & 0 & 308 & 12 \\
Rubira & $\mathrm{P}$ & 85 & 1 & 285 & 11 \\
Rutger's Redleaf & $\mathrm{P}$ & 74 & 9 & 243 & 14 \\
Sapa IR 868-1 [B x S] & $\mathrm{I}$ & 30 & 4 & 270 & 19 \\
St. Anthony IR 870-1 & $\mathrm{I}$ & 13 & 11 & 244 & 29 \\
Tennessee Natural IR 281-1-9 & $\mathrm{P}$ & 71 & 9 & 269 & 13 \\
Tos China \#1 PI 77876 & $\mathrm{P}$ & 63 & 9 & 220 & 14 \\
Wayland & $\mathrm{I}$ & 10 & 9 & 258 & 33 \\
& & & &
\end{tabular}

${ }_{\mathrm{z}}$ op $=$ Open pollinated.

${ }^{\mathrm{A}} \mathrm{A}=$ Prunus armeniaca $; \mathrm{B}=P$. besseyi $; \mathrm{D}=P$. dulcis $; \mathrm{E}=P$. americana $\mathrm{I}=$ interspecific hybrid; $\mathrm{M}=P$. domestica $; \mathrm{O}=P$. spinosa $; \mathrm{P}=P$. persica; $\mathrm{S}=P$. salicina $; \mathrm{U}=P$. munsoniana. Also indicated in brackets for interspecific hybrids.

Table 2. Prunus accessions scored as most limiting of Criconemella xenoplax population increase, but for which few observations were made. The number of observations $(\mathrm{N})$, host suitability score, doubling constant (b), and its SE are shown.

\begin{tabular}{|c|c|c|c|c|c|}
\hline Accession $^{\mathrm{z}}$ & Type $^{y}$ & $\mathrm{~N}$ & Score & $b^{x}$ & SE \\
\hline C12-21 6(50) (probably exotic type) & $\mathrm{P}$ & 9 & 8 & 278 & 35 \\
\hline C4-14-88 & $\mathrm{P}$ & 8 & 6 & 299 & 37 \\
\hline Fairtime & $\mathrm{P}$ & 8 & 13 & 234 & 37 \\
\hline Fayette & $\mathrm{P}$ & 2 & 12 & ND & ND \\
\hline Goldrush & $\mathrm{D}$ & 6 & 2 & ND & ND \\
\hline Irani Olji & A & 4 & 4 & 415 & 53 \\
\hline Ku Chang Hung \#14 Q375-15 & $\mathrm{P}$ & 9 & 8 & 316 & 37 \\
\hline NJ 682227062 & $\mathrm{P}$ & 5 & 11 & ND & ND \\
\hline Outer space & $\mathrm{P}$ & 8 & 15 & 227 & 37 \\
\hline P 52-103 & $\mathrm{P}$ & 4 & 13 & ND & ND \\
\hline P. andersonii & & 4 & 5 & ND & ND \\
\hline P. maritima & & 1 & 13 & ND & ND \\
\hline P. simonii & & 5 & 14 & ND & ND \\
\hline P. texana op & I & 6 & 12 & 233 & 53 \\
\hline Redhaven & $\mathrm{P}$ & 6 & 7 & ND & ND \\
\hline Reliance & $\mathrm{P}$ & 3 & 7 & ND & ND \\
\hline Satsuma & $\mathrm{S}$ & 1 & 14 & 296 & 105 \\
\hline SC 8110-2-139 & $\mathrm{P}$ & 4 & 7 & 323 & 53 \\
\hline Ta Taо \#3 PI 101665 & $\mathrm{P}$ & 9 & 6 & 384 & 43 \\
\hline Tennessee Natural IR 281-1-1 & $\mathrm{P}$ & 4 & 14 & 245 & 53 \\
\hline Tennessee Natural IR 281-1-17 & $\mathrm{P}$ & 6 & 5 & ND & ND \\
\hline Vision & M & 4 & 8 & ND & $\mathrm{N}$ \\
\hline
\end{tabular}

${ }_{\mathrm{z}} \mathrm{op}=$ Open pollinated.

${ }^{\mathrm{y}} \mathrm{A}=$ Prunus armeniaca $; \mathrm{D}=P$. dulcis $; \mathrm{I}=$ interspecific hybrid; $\mathrm{M}=P$. domestica $; \mathrm{P}=P$. persica $; \mathrm{S}=P$. salicina.

${ }^{\mathrm{x}} \mathrm{ND}=$ not determined. 
hortulana-IR 753-1, P 4-13 - and one unnamed accession; two accessions of $P$. insititia-Methley, and St. Julian 53-7; $P$. domestica Mt. Royal; three accessions of $P$. salicina-Frontier, Late Santa Rosa, and PI 494754; and P. tomentosa Orient. There were 26 interspecific hybrids: \#6 R 8.5; ( $\mathrm{S} \times \mathrm{R} .185) 6$; Alf 43-21 (plumcot); Ark 7993; BY 68-071; BY 68-389; BY 68-87; BY 7401-5; BY 8-3908; Deep Purple IR 867-1; Dura IR 789-2; $\mathrm{F}_{1}(P$. fenzliana $\times$ P. bucharica)x; Goff IR 972-1; Isthara; Kaga; Mansan IR 740-1; Monitor IR 574-3; NCA 10254; Opata IR 554-3; $P$. besseyi $\times$ peach; peach $\times$ P. cerasifera var divaricata (ot); R9.5; S 2729; Sapa Q84-10A-01 A; Superior IR 544-2; and Wessex Q22109B. There were eight nectarines: 14DR51; 14DR52; 14DR56; 14DR57; Brandy Morton; Darwin PI 131430; NH 62 N; and Violette Hative PI 131075. Finally, 128 peach accessions were included in this group: 152-AI-2RH-2; 20-11 S37op $x$ [(RRL $x$ Yunnan)F5] =FV331-43op; 20-4 S37op $\times$ [(RRL $x$ Yunnan)F5] $=$ FV331-43op; 3-12 S37op x [(RRL x Yunnan)F5] = FV331-43op; 3-6 S37op x [(RRL x Yunnan)F5] = FV331-43op; 40-12 S37op X [(RRL x Yunnan)F5] = FV331-43op; 40-2 S37op $x$ [(RRL $x$ Yunnan)F5] =FV331-43op; 40-3 S37op $\times$ [(RRL $\times$ Yunnan)F5] = FV331-43op; 520-3 B594520 op = [(Nemaguard op)op]op; 5208 B594520 op $=[($ Nemaguard op $)$ op $]$ op; 520-9 B594520 op = [(Nem op)op]op; 58 RL 255; 9-1 S37op $\times$ [(RRL $x$ Yunnan)F5] = FV331-43 op; 9-10 S37op x [(RRL x Yunnan)F5] = FV331-43op; 9-13 S37op x [(RRL x Yunnan)F5] = FV331-43op; Agua 6-4; Amarillo Tardio; Amber Mutant; Appia; Ark 7759; Ark 7762; Ark 7763; Ark 7774; Ark 7861; Baladi 1 PI 82413; Boone Co. IR 501-1; Boone Co. MSU 6(62); Bulgarian 11-23; Candor; Carman IR 1055-2; Carnival; Chinese Blood IR 831-1; Chinese Cling; Cohagen Natural (Nicholson); Dwarf Mandrin; Eagle Beak PI 43289; Early Amber; Elbertita; Ferganensis (Ark); Ferganensis 6(42) (off type); Ferganensis op; FL 14-4; FL 7-7; FL 8-110; Flordaguard (FL 1411); Florida Late Peento; FV 3-2; G.X. PI 132742; Gabriella; Gold Medal IR 63-7-2; Hakuto; Harrow Blood; Harvest Gold; Holbrook sdlg.; Hollister sdlg. (Nicholson); Indian Blood; Inkoos PI 93826; J68-52 Nemaguard x Tenn. Nat. sel.; Khidetavsky PI 119836; Lemon Free (Walker); Loring; Lovell x Nemaguard; Mao Tao sdlg.; Marsun; Mexican Honey; N-3; Nemaguard \#3; Newhaven X 7720(Poland); NHNC 3; NJ 249; NJ 27043; NJ 27240; NJ 5110418; NJ 554774; NJ 632143089; NJ 682097006; NJC 97; Nooiens Herholdts PI 133987; NRL-2; Okinawa; P 115-103 [Nemaguard X (Yunnan $X$ redleaf)]; P 115-107 [Nemaguard $X$ (Yunnan $X$ redleaf)]; P 115-25 [Nemaguard $X$ (Yunnan $X$ redleaf)]; P 115-46[Nemaguard X (Yunnan X redleaf)]; P 31-31 op PI 430894; P 31-34 op PI 430895; P 31-38 op PI 430896; P 31-42 op PI 430899; P 6-40; Peppermint; Platycarpa PI 119846; Polar IR 915-1-ND-3; Polly IR 518-1-6; Prairie Dawn; Precoce d'Ampuis PI 101835; Quiney Wilding (Nicholson); R76; Redbrite; Redglobe; Redqueen; Rheingold PI 132007; Rogani-Gow PI 113452; Saharanpur 1 PI 112032; Salway; Saturn; SC 81074; SC 83109 op (Majestic x P8949); SC 83154 op; SC 83157 op; SCRS-1; SCRS-10; SCRS-3; SCRS-6; Shirim-Damak PI 119839; Sunqueen IR 780-2; Ta Tao \#1 PI 101663; Ta Tao \#5 PI 101667; Ta Tao \#6 PI 101668; Ta Tao sdlg. MSU 3(34); Tennessee Natural (SH\#129); Tennessee Natural J67-34; Tennessee Natural R4; Tennessee Natural sel. (NA8); Transvaal Yellow; Triogem; WC-107 Borer Resistant; Xavante; and Yumyeong.

The other 173 accessions were highly suitable hosts that have been examined in greater numbers (10 to 128 observations). Included among these were the following: $P$. cistena IR 80-1; $P$. pumila; P. webbii (SB \#18 1-46); Tlor Ciran (exotic plum); two accessions of $P$. besseyi-3-24 and Sioux IR 263-1; five accessions of P. cerasifer-20-2 IR 869-1, Myrabi P 2032, Wa 1005 IR
370, Wa 1201 IR 372-3, and Wa 1230 IR 283-1; P. angustifolia FL 1-2; $P$. insititia St. Julian X; $P$. domestica GF 43; two accessions of $P$. salicina-Duarte 182 and Pipestone; and $P$. tomentosa IR 473-1. Also included are 28 interspecific hybrids as follows: \#1 R 8.5; All Red IR 545-1; Ark 7991; Ark 7995; Ark PR 11; Compass IR 969-1; F5 22-10; GF 557; GF 677; Hanska IR 551-1; Hazel IR 965-1; IR 473-1; Lantz IR 546-3; Marianna 2624 IR 131-1; Myran; $P$. davidiana $\times$ peach; $P$. texana $\times$ FL 1-2; Pobeda Q36-A03A; Pollardi PI 113650; Sapalta IR 549-1; South Dakota IR 79-1; Temptation Q36-05A; Toka IR 432-1; Underwood IR 231-2; Waneta IR 553-2; Zaiger F3 peach $\mathrm{x}$ almond; Zapie; and Early Crimea. There were nine nectarines: DeCoosa PI 65974; Lady Palmerston PI 133741; P 10 - 58 (Fresno); Panamint; Peregrine PI 133551; Pineapple PI 131209; Quetta PI 34685; Sary Oilor PI 125017; and White Weeping (NC). Finally, there were $119 P$. persica accessions: \#01370 USSR PI 117679; (Massasoit $x$ self) F2; 16-167; 174RL; 181 Peach; 49-12 S37op x [(RRL x Yunnan)F5] = FV331-43op; 49-7 S37op $\times$ [(RRL $x$ Yunnan $) F 5]=$ FV33143op; Adria; Agua 12-12; Agua 12-13; Angel PI 129674; Ark 7771; Autumn Lady; Bailey; Baronesa; Bienvenida PI 101823; Bolivian Cling PI 36126; Boone Co. (Byron); Bresquillo Duraznos Sel. Sdlg. PI 134150; C11-12 15(22); C12-25 4(37); C12-269(61); Chu Hun Tao; Comofort; Dalton Ornamental; Dew Drop; Erica Rudolph PI 132739; Ferganensis \#02446 (off type) PI 113455; Ferris Strain; FL 3-1; FL 81-11; Frank IR 504-1-1; G'aschina Novembre PI 104488; Galway Bay; Gaucho; Genovese PI 105362; GF 305; Hagan Sweet; Halford; Heath Cling; Herholdt's Late Cling PI 133982; Higama; Indian Cling Clemson; K 62-67; K 6268; Kakamas Q541-01; Khodjent Kostokos PI 102705; Killiekrankie PI 106062; Leaf Curl Resistant Q457-01A; Lemon Cling sdlg. (Sidle); Lovell; Mao Tao Q375-07C; Marina PI 133984; Mexico PI 442380; Minnesota sdlg.; Montclar; N-7; Nemaguard; Nemaguard \#2; Nemared; NJ 5110417; NRL-1; P 101-40 Lovell $x$ Nemared; P 101-41 Lovell x Nemared; P 115-102 [Nemaguard $X$ (Yunnan $X$ redleaf)]; P 115-104 -[Nemaguard $X$ (Yunnan $X$ redleaf)]; P 115-32 [Nemaguard $X$ (Yunnan $X$ redleaf)]; P 115-5 [Nemaguard $x$ (Yunnan $x$ redleaf)]; P 115-95 [Nemaguard $x$ (Yunnan $x$ redleaf)]; P 31-24 op PI 430892; P 31-27 op PI 430892; P 31-29 op PI 430892; P 31-30 op PI 430893; Pi Tao PI 62602; Pillar; Pillar L-1; Pillar L-2; Pistora; Polly IR 518-1-1; Prairie Rose IR 202-2A; Prodigiosa Q727-07A1; Proskaeur PI 130980; Red Baron; Red Weeping PI 91459; Red Wing IR 989-6; Rosie Mamorata; Royal George PI 151158; Ruston Red; S-37; Saharanpur 2 PI 112033; Salcaja; Sel. sdlg. China PI 134401; Sel. sdlg. USSR PI 146137; Shalil op PI 63850; Siberian C; Sihung Chui Mi Q1-03; Slappey; Soliel d'Octobre PI 104287; Spathe de Hallen PI 131034; Stoney Hard 7-28; Ta Tao \#19; Ta Tao sdlg.; Tennessee Natural IR 282-11; Tennessee Natural IR 282-2-6; Tennessee Natural IR 282 7-6; Tennessee Natural R2; Tennessee Natural R27; Terzarola col Pizzo PI 78544; Turnip shaped PI 119840; Tzim Pee Tao; W-1; White English; White Walton; Winter 184; Yellow Yunnan IR 843-1; Yennoh PI 78513; Yugoslavia Q1-04; Yunnan PI 55776; and Zatrani.

\section{Discussion}

Among the 410 accessions tested as hosts for C.xenoplax, none consistently prevented nematode population increase. A substantial component of the variance was associated with differences among accessions, but repeated testing of candidates always confirmed high suitability as hosts in at least some trials. Although a few accessions probably should be examined further, these most likely are highly suitable hosts as well. 
Prunus selections that are unsuitable as hosts for the ring nematode may not exist, since this nematode has a very broad host range including species in diverse plant families (Raski and Radewald, 1958; Ruehle, 1966, 1971; Sher, 1959; Zehr et al., 1986, 1990). The fact that no Prunus spp. have been reported resistant to C. xenoplax (Goodey and Franklin, 1956; Lownsbery, 1964; Mojtahedi and Lownsbery, 1975; Seshadri, 1964) and that we found only moderate resistance among a few accessions lends substantial support to this hypothesis. Taken together, the evidence suggests that further attempts to find natural resistance to $C$. xenoplax may not be warranted.

An appropriate incubation period for experiments designed similar to those conducted in 1985-86 can be recommended. The variance component was highest and nematode population increase remained rapid after a 14-week incubation. This suggests that a 14-week incubation may provide the greatest separation of accessions based on nematode population densities and the best information about host suitability for experiments of this design. This is similar to the incubation period suggested by the greenhouse growth model for this nematode (Westcott and Burrows, 1990).

With respect to those tests conducted in 1987-90, a highly suitable host would have a $\beta$ of 139 degree-days (Westcott and Zehr, 1991). It seems that $\beta$ is too sensitive in the range of low host suitability (Fig. 3) and the population is not normally distributed. This arises from the nature of this measure of nematode population increase (Westcott and Burrows, 1990). As population increase nears 0 for an incubation period, $\beta$ rapidly increases. It remains to be determined what values of $\beta$ would characterize effective resistance in the field.

The utility of any selection as a rootstock for peach to suppress $C$. xenoplax must be assessed in field tests to verify that $C$. xenoplax does not increase to damaging levels under normal orchard conditions, or that the selection is not severely injured due to extreme sensitivity to the nematode. As an alternative to resistance, field tolerance to $C$. xenoplax may be a mechanism involved in reducing early tree death (Reighard et al., 1989; Westcott and Zehr, 1991). Eliminating the ring nematode as a problem using an unsuitable host as a rootstock may improve longevity of peaches on nematode-infested sites. However, $C$. xenoplax has a broad host range, and even those selections that seem to limit nematode population increase probably will not reduce population densities in the field sufficiently. If resistance is eventually found, improved understanding of this phenomenon may be used to develop new ways to limit nematode damage to peach trees in the orchard.

\section{Literature Cited}

Byrd, Jr., D.W., K.R. Barker, H. Ferris, C.J. Nusbaum, W.E. Griffin, R.H. Small, and C.A. Stone. 1976. Two semi-automatic elutriators for extracting nematodes and certain fungi from soil. J. Nematol. 8:206-212. Cain, D.W., E.I. Zehr, W.R. Okie, and A.P. Nyczepir. 1988. Screening of Prunus germplasm for resistance to C.xenoplax and peach tree short life, p. 31-33. In: E.I. Zehr (ed.). Stone tree fruit decline workshop. 3rd Proc. U.S. Dept. Agr., Agr. Res. Serv.
Chandler, W.A. 1969. Reduction in mortality of peach trees following preplant soil fumigation. Plant Dis. Rpt. 53:49-53.

Dozier, Jr., W.A., J.W. Knowles, C.C. Carlton, R.C. Rom, E.H. Arrington, E.J. Wehunt, U.L. Yadava, S.L. Doud, D.F. Ritchie, C.N. Clayton, E.I. Zehr, C.E. Gambrell, J.A. Britton, and D.W. Lockwood. 1984. Survival, growth, and yield of peach trees as affected by rootstocks. HortScience 19:26-30.

Eayre, C.G., B.A. Jaffee, and E.I.Zehr. 1987. Suppression of Criconemella xenoplax by the nematophagous fungus Hirsutella rhossiliensis. Plant Dis. 71:832-834.

Goodey, J.B. and M.T. Franklin. 1956. The nematode parasites of plants catalogued under their hosts. Commun. Agr. Bur., Farnham Royal, Bucks, England.

Harter, H.L. 1961. Expected values of normal order statistics. Biometrika 48:151-165.

Jenkins, W.R. 1964. A rapid centrifugal-flotation technique for separating nematodes from soil. Plant Dis. Rpt. 48:692.

Lownsbery, B.F. 1964. Effects of cropping on population levels of Xiphinema americanum and Criconemoides xenoplax. Plant Dis. Rpt. 48:218-221.

Mojtahedi, H. and B.F. Lownsbery. 1975. Pathogenicity of Criconemoides xenoplax to prune and plum rootstocks. J. Nematol. 7:114-119.

Nyczepir, A.P., E.I. Zehr, S.A. Lewis, and D.C. Harshman. 1983. Short life of peach trees induced by Criconemella xenoplax. Plant Dis. 67:507-508.

Raski, D.J. and J.D. Radewald. 1958. Reproduction and symptomology of certain ectoparasitic nematodes on roots of Thompson seedless grape. Plant Dis. Rpt. 42:941-943.

Reighard, G.L., W.C. Newall, Jr., and D.W. Cain. 1989. Screening Prunus germplasm for potential rootstocks for South Carolina, USA replant sites. Acta Hort. 254:287-290.

Ritchie, D.F. 1984. Control of Criconemella xenoplax and Meloidogyne incognita and improved peach tree survival following multiple fall applications of fenamiphos. Plant Dis. 68:477-480.

Ruehle, J.L. 1966. Nematodes parasitic on forest trees. I. Reproduction of ectoparasites on pines. Nematologica 12:443-447.

Ruehle, J.L. 1971. Nematodes parasitic on forest trees. III. Reproduction on selected hardwoods. J. Nematol. 3:170-173.

Seshadri, A.R. 1964. Investigations of the biology and life cycle of Criconemoides xenoplax Raski, 1952 (Nematoda: Criconematidae). Nematologica 10:540-562.

Sher, S.A. 1959. A disease of carnations caused by the nematode Criconemoides xenoplax. Phytopathology 49:761-763.

Westcott, S.W. and P.M. Burrows. 1991. Degree-day models for predicting egg hatch and population increase of Criconemella xenoplax. J. Nematol. 23:386-392.

Westcott, S.W. and E.I. Zehr. 1991. Evaluation of host suitability in Prunus for Criconemella xenoplax. J. Nematol. 23:393-401.

Zehr, E.I., J.B. Aitken, J.M. Scott, and J.R. Meyer. 1990. Additional hosts for the ring nematode, Criconemella xenoplax. J. Nematol. 22:86-89.

Zehr, E.I. and J.K. Golden. 1986. Strip and broadcast treatments of dichloropropene compared for controlling Criconemella xenoplax and short life in a peach orchard. Plant Dis. 70:1064-1066.

Zehr, E.I., S.A. Lewis, and M.J. Bonner. 1986. Some herbaceous hosts of the ring nematode (Criconemella xenoplax). Plant Dis. 70:1066-1069.

Zehr, E.I., S.A. Lewis, and C.E. Gambrell, Jr. 1982. Effectiveness of certain nematicides for control of Macroposthonia xenoplax and short life of peach trees. Plant Dis. 66:225-228.

Zehr, E.I., R.W. Miller, and F.H. Smith. 1976. Soil fumigation and peach rootstocks for protection against peach tree short life. Phytopathology 66:689-694. 